\title{
AT THE BASE OF ROME'S PECULIUM ECONOMY
}

\author{
Morris Silver***
}

Keywords: peculium; ut manumittatur; self-purchase; contractual slave; indentured servitude; imperfections in capital market; oath

\section{Why were Roman slaves allowed to have a peculium?}

Surprisingly, this is not a question to which Roman scholars have devoted a great deal of economic analysis. One noteworthy exception is Keith Hopkins: ${ }^{1}$

The concept 'peculium' applied originally to the money which a father allowed a son, who was still under his authority; in our sources, however, it is most commonly used to describe a slave's possessions. The institution of peculium allowed the slave a working capital, 'borrowed' from his master ... The very idea that slaves could de facto control their own property, including their own slaves, implied independence of action ... The slave's desire to buy his freedom was the master's protection against laziness and shoddy work - although

$1 \quad$ 1978: $125-128$.

* Professor Emeritus of Economics, City College of the City University of New York.

** My thanks to Richard Gamauf and Egbert Koops for suggestions and penetrating criticisms and to Rena van den Bergh for her generous editorial assistance. I am responsible for any remaining errors. My research benefited greatly from the conscientious assistance of Evelyn Bodden and her staff of the Interlibrary Loan Department in the Cohen Library in the City College of New York. 
the slave might also cheat his master to speed his chances of buying freedom. The slave had freedom to work for. The master held out the carrot as well as the stick; the stick itself, as the American experience showed, was ineffectual. The cost of providing an incentive for good work was liberty ... Of course, it was not a legal contract ... but in general the 'contract' was honoured ... In the final analysis, the liberation of so many slaves was acceptable to masters only because it was profitable. As we have seen, masters derived some of their profit from the extra work which favoured slaves did under the spur of freedom enticingly visible on the horizon.

Basically, what Hopkins is suggesting, is that by granting peculia masters sought to lower their costs of supervision by encouraging slaves to self-enforce the performance of their assigned duties. Hopkins' understanding is explicitly supported by Garnsey ${ }^{2}$ and also by Zwalve ${ }^{3}$ when he calls the peculium "a bellissima machinato originating from the hard and cynical legal minds of the likes of Cato who perceived that the prospect of liberty by industry is one of the strongest incentives of human ingenuity and resourcefulness".

Upon this peculium base is erected, or so it would appear, an impressive Roman legal and commercial superstructure. Thus, in commenting on its legal implications, Gamauf notes that the peculium "conferred upon the slave unrestricted powers to acquire without requiring accompanying surveillance by the master". ${ }^{4}$ Fleckner $^{5}$ elaborates: "For those who exert authority, the grant of peculium offers the prospect of participating indirectly, and therefore at lower risk, in business ventures that the recipient may conduct; the peculium could then be seen as an instrument for investments in business enterprises." The businesses managed by slaves might be located "beyond the sea or in regions where they [the owners] are not living themselves ....". Again, Ulpian ${ }^{7}$ takes note of Labeo's discussion "about a provincial who, in order to sell his merchandise, has a slave keeping a shop in Rome". In the countryside, bailiffs (vilici) ran estates far from the estates of their owners. ${ }^{8}$

Not only might slaves with a peculium and libera administratio ("license to administer") conclude legal contracts with third parties, but they could also do so with their owners. ${ }^{9}$ In this connection, Martin ${ }^{10}$ calls attention to Cicero $Q F r ~ 31$ 5-6 wherein Cicero writes to Quintus:

Your bailiff (vilicus) Nicephorus impressed me very favorably. I asked him whether you had given him any instructions about that little bit of building at Laterium of

2 1981: 362-363.

3 2002: 127.

4 2009: 339.

5 2014: 219.

6 D 40910 Gaius (tr Watson).

7 D 51193.

8 Laes 2008: 249, citing mainly Apuleius Metamorphoses.

9 Carlsen 1995: 99 with nn 325, 326 citing D 121613 and D 137184.

10 1989: 55-57. 
which you had spoken to me. He answered that he had contracted to do the job himself (the technical term conductorem) for 16,000 sesterces, but that you had later made considerable additions to the work and none to the price, so he had done nothing about it. $^{11}$

Thus, not only might a slave form a contract with his owner, but he could decline to perform if the latter introduced cost-raising conditions. With respect to the legal status of Nicephorus, there is ample evidence of slave vilici and little or none of free vilici. ${ }^{12}$ That Nicephorus made a legal building contract with Quintus provides no basis for assuming that he was free any more than his making a self-purchase contract with Quintus would have done. ${ }^{13}$

A dramatic illustration of the peculium economy at work is provided in the report of Hippolytus regarding the banking career of the slave Callistus, who became Pope in $217 \mathrm{CE}$. As a young slave, Callistus received a large sum of money from his owner Carpophorus (an imperial slave) with the "instruction/order to bring him profits from banking deals". ${ }^{14}$ As noted by Andreau, ${ }^{15}$ this scenario suggests that the sum given to Callistus was a peculium and, despite legal irregularities, it appears that Carpophorus received regular "dividends" from the profits of a banking enterprise independently managed by his slave Callistus.

Moreover, the grant of a peculium offers a legal vehicle for building large enterprises: "Instead of running the business on his own, he [the master] could transfer the funds and assets to one of his slaves and thereby limit his risk, in general to the current value of the peculium ... In this way, the master could set up a business enterprise with a sort of limited liability ... Now, if several masters pooled their funds and vested a common slave with the capital, they could mitigate some of the structural disadvantages of the societas ..." enterprises actually existed remains an open question.

This article points out that forcibly taken slaves (including born-slaves), the kind taken for granted by Hopkins and in most of the literature, would be insufficiently incentivised by peculia. It is argued that the peculium economy is nevertheless able

11 Letter to Quintus 21 (tr Shackleton Bailey 2014).

12 Roman vilici ("stewards/bailiffs") were typically slaves (Beare 1978: esp 398; Carlsen 1995: esp 202; Schumacher 2011: passim). Scheidel 1990 provides evidence for free-born bailiffs but this is not evidence for free bailiffs. To gain employment in such financially sensitive positions individuals probably had to volunteer for slavery. Estate owners, especially absentees or those otherwise occupied, preferred slaves to free employees because those suspected of peculation or careless behavior could legally be put to torture. The use of volunteer slaves in sensitive financial positions is found not only in Rome but also among Early Modern Russia's "registered" (administrative/financial) slaves - "he who has the key shall be a slave" (Hellie 1982: 36-39). Hellie (1982: 36) furthermore remarks that contemporary observers have been baffled by the fact that "scions of the important, genealogically ranked families ... sold themselves into slavery".

13 See 3 supra.

14 Refutation of All Heresies 912 1-12 (tr Andreau 2006: 207).

15 2006: 205-208.

16 Fleckner 2014: 222; cf Földi 1996: 201-205. 
to stand as a dominant Roman socio-economic reality because the slaves forming its base are slaves by contract/self-sellers.

\section{The self-enforcement explanation is not credible}

Upon further review the proposition that allowing a slave to possess and grow a peculium encourages him to self-enforce his effort, is self-negating and, hence, problematic. The master has no contract or agreement with his slave, from whom he extracts labor by physical force. "Slaves were forcibly imported aliens who were exploited to a degree and in a way which citizens would not allow." ${ }^{17}$ Bradley $^{18}$ expands on this theme: "[S]lavery as an institution was based ultimately on the violent subjection of one person to another that arose from the dominating power claimed when life was spared upon defeat in warfare ... So slaves were always at war with their owners ..." He also maintains: "Escape was a direct form of resistance to slavery by means of which the slave rejected his subjection to the authority of his master in favor of securing his freedom." 19

Unfortunately, there are no slave diaries or other slave accounts from ancient Rome. It is possible to supplement empathy with other kinds of evidence, however. Plautus's slave owner Hegio helps to confirm Bradley's insight into slave psychology: "A free man taken prisoner (liber captivus) is like a wild bird: once he's given a chance of escape, it's enough, you can never catch him afterwards." ${ }^{20}$ Hegio's "free captive" prisoners of war were to be kept in chains which is hardly conducive to discretionary services. Macer anticipates that a criminal slave who was whipped and then returned to serve the remainder of his sentence in chains (vincula) might not be accepted back by his owner. ${ }^{21}$

The trust/resentment problem inherent in forcible slavery cannot be solved by asserting that many slaves were slaves by birth and not by way of war or piracy. Even if this was true, and direct evidence on the fertility of Roman slaves is lacking, ${ }^{22}$ the slave status of "houseborn" children rests solely on the violent subjection of their parents. These "vernae," just as much as their parents taken in open war and raids, are outsiders enslaved by physical force. Why else would they be slaves? For houseborn slaves, however, the trauma of capture increased over a lifetime and they must have viewed their subjection as totally unjust. The war with owners was the inheritance of born slaves, and peculia would rarely be awarded to enemies.

17 Hopkins 1978: 112.

18 2010: 630 .

19 1989: 38.

20 The Captives 110-119 (tr De Melo 2011).

21 D $481910 p r$.

22 The estimates of slave fertility cited in the literature are based on demographic modeling, and not on actual evidence of Roman slave fertility. For a full critique and references, see Silver 2011a: 109-113. 
It follows from the deep adversarial relationship between a typical slave (whether houseborn or war prisoner) and owner that any diminution of supervision would have the immediate effect of facilitating escape (or revenge) and, indeed, the possession of property (money, goods or slaves) would have the immediate effect of increasing the odds that the slave would make good on his escape. But the opposing behavioral effects of granting peculia to slaves - slaves with a peculium work harder and slaves with a peculium run away - do not simply tend to cancel out. As a product of human evolution, a forcibly enslaved individual is much less motivated to gradually accumulate a ransom for the thief who has stolen his life than to resist his thief and reclaim his rightful status of free man. Masters knew better than to believe that slaves would wait patiently for manumission to legally depart with their purses and/or accumulate cash to pay their ransom. The point is simple: Rome's extensive peculium economy could not possibly have rested on a base as fragile and uncertain as self-supervised forcible captives.

It is not easy to demonstrate the limited economic value of actual prisoners of war but we do have Strabo's ${ }^{23}$ contemporary observations about forcibly taken Corsicans: "At any rate, whenever, the Roman generals have made a sally, and falling suddenly upon the strongholds, have taken a large number of people as slaves, you can at Rome see and marvel at, the extent to which the nature of wild beasts, as also that of battening cattle, is manifested in them; for either they cannot endure to live in captivity, or, if they do live, they so irritate their purchasers by their apathy and insensibility, that, even though the purchasers may have paid for them no more than an insignificant sum, nevertheless they repent the purchase." Slave owners would be well aware of the intense resentment and demoralisation felt by forcibly taken captives and would not be inclined to grant them a peculium, and thereby to subsidise the flight of their property. ${ }^{24}$ Very little is known about the ultimate destinations of prisoners of war. However, it is reasonable to assume that, if enslaved, such hostile and dangerous individuals would normally be allocated to easily policed labours whether in offices and factories, or much more rigorously in mills, mining, road repair; they would be granted little or no freedom, including even the opportunity to reproduce. ${ }^{25}$ Seneca sympathises with the "prisoner of war (captivus), who having

23 Strabo 527 (tr Jones 1924).

24 Silver 2011a: 95-96.

25 For war captives sent to dig Nero's canal, see Josephus Jewish Wars 3 540; for slaves sent to mills (pistrinum): Millar 1984: esp 143-144. Cicero (Letters to Atticus 416 7) cautioned in 54 $\mathrm{BCE}$ that war captives from Britain would not include many qualified in literature and music. The implication being that skilled captives were assigned within their areas of expertise. Still, owners would bear the extra cost of carefully controlling them. The Romans were quite interested in the ethnic origin of slaves (D 211 31; D 50154 5; cf Varro De Lingua Latina 9 93). Ethnic origin conveyed information to purchasers including, I suspect, whether a slave was more likely to have been a forcible captive than a volunteer/self-seller (see 4 infra). This, it is argued, was the distinction that operated to bifurcate the Roman market for labour-power, not legal status as a slave. 
suddenly been reduced to the condition of a slave, still retains some remnants of liberty, and does not run nimbly to perform foul and toilsome tasks $\ldots{ }^{26}$

It is even more difficult to present specific evidence bearing on the resentment harbored by the offspring, if there were any, of forcibly taken captives. "Slave children are rarely mentioned in literature. They remain invisible. We learn hardly anything about their life or relations to parents and masters ... In the legal texts too, vernae are mentioned very infrequently." ${ }^{27}$ There is some evidence for especially young captives, however. Cato the Elder, says Plutarch ${ }^{28}$ "owned many domestics and usually bought those prisoners of war (aichmalotos) who were young and still capable of being reared and trained like whelps or colts. Not one of his slaves ever entered another man's house unless sent thither by Cato or his wife ..." I take this restriction on free movement to mean that Cato had little trust in his youthful forcible captives. A counter-example, albeit fictional, is provided by the absolute loyalty of the swineherd Eumaios who had been kidnapped as a child and then sold to Odysseus. ${ }^{29}$

Of course, the above examples do not prove that forcibly taken captives were typically distrusted. On the other hand, there are no real life examples indicating that owners trusted them.

\section{The peculium and the peculium economy are not myths}

It is the understanding of the (at best) mixed consequences of granting a peculium to a forcibly enslaved person (the only kind usually recognised in orthodox scholarship) that probably explains why some scholars seem to regard the peculium with suspicion.

However, references to self-purchase are commonplace not only in comedy, also but in other kinds of literary sources, in epigraphy, and in legal texts. Koops (forthcoming) notes almost 200 references to aspects of self-purchase in legal texts alone. As early as c 450 BCE, Rome's Law of the Twelve Tables 58 takes note of freedmen with inheritances and 712 envisions self-purchase: "A slave is ordered in a will to be a free man under this condition: 'if he has given 10,000 asses to the heir'; although the slave has been alienated by the heir, yet the slave by giving the said money to the buyer shall enter into his freedom ...." ${ }^{30}$ In Digest 12435 Ulpian illustrates his legal argument by noting that "Neratius tells in his book, Parchments, how Paris the dancer recovered before a judge from Domitia, daughter of Nero, the ten [ten thousand?] he had paid her for his freedom ..."31 A slave takes over

On Anger 3291 (tr Stewart 1900).

27 See Sigismund Nielsen 1991: 226-227.

28 See Cato 211 (tr Perrin 1914).

29 Homer Odyssey 14 56-61, 15 390-484.

30 Translated by Johnson et al 1961.

31 Cf Tacitus Annals 1327. 
the owner's liability for a debt in lieu of payment for freedom in Digest 151111 (Ulpian). A slave might borrow money on the loan market to purchase freedom: "A slave whom I thought to be mine borrowed money from Titius and gave it to me in return for freedom." 32

Once payment had been made the manumission contract/agreement could not be rescinded by the owner of the slave. ${ }^{33}$ If the manumission preceded the payment the owner still had the right to collect the agreed sum from his former slave. ${ }^{34} \mathrm{In}$ Digest 40119 Papinian states as follows: "If anyone received cash from another person so that he may manumit his slave, the slave's freedom can be wrung even from the unwilling master, although very commonly it is the slave's money that is paid out, especially if the money has been given by his natural brother or father, in fact he will resemble the slave who has been purchased with his own cash." For an attempt to aid slaves by imposing an upper limit on payments for freedom, see Ulpian ${ }^{35}$ who refers to the shadowy edict of the praetor Rutilius Rufus in about 118 BCE. Bargaining over the price of manumission is explicitly mentioned by Alfenus Varus: "A slave had bargained (pactus) for freedom in return for money and paid the money to the master ..." 36

In Annals 1442 Tacitus tells that an outraged slave killed his owner when he refused to free him at the agreed price. In a famous funerary inscription from Assisi the physician Publius Decimius Eros Merula records that he paid the substantial sum of 50,000 sesterces to purchase his freedom. ${ }^{37}$ Tityrus mentions his laziness which prevented him from accumulating a sufficient peculium together with the result that freedom (libertas) came to him only at an advanced age. ${ }^{38}$ Martial ${ }^{39}$ refers to selfpurchase: "Because I now address you by your name, when I used before to call you lord and master, do not regard me as presumptuous. At the price of all my chattels I have purchased my cap of liberty. He only wants lords and masters who cannot

32 See D 151503 (Papinian); cf D 15 33pr 4016 (Ulpian); Alfenus Varus 1532 (Javolenus). It is difficult to know how to take Achilles Tatius 517 which apparently dates to the second century CE. Here we have a number of standard elements: Lacaena, a free woman from Thessaly, is taken by "pirates" and later sold in Ephesus by a slave dealer to a lustful steward; the fettered woman displays her scars from resisting his sexual demands and then is freed by the wealthy Melitte (the owner of the steward?) and returned to Thessaly. What does not seem to fit the clichéd account is that Lacaena attempts to purchase her freedom with borrowed cash when she says to Melitte: "Save me from this threatening disaster, grant me security until I pay you the two thousand pieces of gold; that was the sum for which Sothenes [the steward] bought me from the hands of the pirates, and be sure that I can raise it with very small delay; if not, I will be your slave" (tr Gaselee 1917). Lacaena can pledge control over her body to obtain a loan.

33 C 71633 (dated 294 CE).

34 D 44522.

35 D 38211.

36 D 4016.

37 Corpus Inscriptionum Latinarum 115400 (hereafter CIL).

38 See Virgil Eclogue $127 \mathrm{ff}$ (tr Fairclough; but $c f$ Mouritsen 2011: 162).

39 See Epigrams 268 (tr Ker 1920). 
govern himself and who covets what lords and masters covet. If you can do without a servant, Olus, you can do without a master." Seneca, in the Letters to Lucilium wrote: ${ }^{40}$ "And what do you need in order to become good? To wish it. But what better thing could you wish for than to break away from this slavery, a slavery that oppresses us all, a slavery which even chattels of the lowest estate, born amid such degradation, strive in every possible way to strip off? In exchange for freedom they pay out the savings which they have scraped together by cheating their own bellies; shall you not be eager to attain liberty at any price, seeing that you claim it as your birthright?" This passage permeated by Stoic ideology at least grants that payment for freedom was made by ordinary slaves, not just by entertainers and physicians. Similarly, Dionysus of Halicarnassus ${ }^{41}$ observes a trend which has slaves increasingly paying for freedom with their earnings in sordid labours (crime and prostitution). ${ }^{42}$ Further, there are grounds for believing that the self-purchase agreement (pactum libertatis) "was even actionable on the part of the slave: if his master failed to set him free on being offered the price agreed upon, the slave could file a complaint with the praefectus urbi or the praeses provinciae". ${ }^{43}$ Note also what Ulpian has to say in Digest 29271 2: "If someone had given money to his master in order to be manumitted, I think that assistance should be given to him in every case."

That even ordinary agricultural slaves possessed peculia is suggested by Cato's scheme to charge male slaves a fee for access to the female slave quarters, ${ }^{44}$ and is explicitly stated by Varro. ${ }^{45}$ The peculia of agricultural slaves included cash, animals, and slaves. ${ }^{46}$ The bylaws of the Collegium Dianae et Antinoi from the Italian town of Lanuvium dated to $136 \mathrm{CE}$ state that slaves might belong and, like free members, they had to pay a membership fee and annual dues; if manumitted, a member slave was expected to contribute "an amphora of good wine" to the association. ${ }^{47} \mathrm{~A}$ female slave might use her peculium to give a "dowry" (dos) to a male slave ${ }^{48}$ or, apparently, to buy a tomb: "Valeria Lycisca, freedwoman of a woman. At the age of 12, I came to Rome, which gave me the rights of a citizen and gave me, still living, a place where I would be taken when I became a bag of ash." ${ }^{49}$

The peculium is perfectly real and not exclusively urban but its prevalence cannot be explained by the proposition that it was intended to motivate effort by forcibly taken slaves. Given the slave owner's contractual liability, as Aubert ${ }^{50}$ points

$40 \quad$ At 804.

41 At 424 1-6 (tr Gummere 1925).

42 For other examples of cash payments for manumission, see Mouritsen 2011: 162-66; Rawson 1993: 221; Schumacher 2011: 595; and, most likely, Cicero Philippics 832.

43 Zwalve 2002: 122 citing D 40 15pr; cf D 112 11; D 401 19; C 4 57 4; and D 7168.

44 Plutarch Cato the Elder 212.

45 Res Rustica 12 17, 119 3; cf Roth 2005: 282.

46 CIL 11871 as discussed by Roth 2005: 288-289.

47 CIL 14 2112; Bendlin 2011.

48 See D $23339 p r$.

49 CIL D 628228 (tr MacLean 2012: 202); CIL 68495 for purchase of a tomb by an imperial slave. 
out, he would be inclined to grant a peculium to "well-tested, trustworthy servants", which hardly describes forcible captives (recall the Corsicans). A forcible captive might even swear to the owner not to run away with his purse or not to use it to commit mischief against his master but no one would believe him as he would not feel morally bound to honor a promise to his kidnapper. The impressive superstructure (the peculium economy) is likewise perfectly real but its defining lack of supervision is incompatible with the prevalence of forced slavery. It cannot be supported on the shoulders of a residue of captives with abnormal psychologies.

\section{$4 \quad$ The peculium is a benefit negotiated by free individuals}

The peculium and the peculium economy can be made to rest on a solid base. The outlines of a solution become visible once it is wondered whether an unsupervised slave who did not "take the money (or sheep) and run" is really a forcibly taken captive.

The solution to the problem of the peculium is not that it emerged as a one-sided device for manipulating a helpless captive, as assumed by Hopkins, Bradley ${ }^{51}$ and Cohen ${ }^{52}$ or as a gift, as considered by Fleckner ${ }^{53}$ but rather the peculium is a contractual benefit desired by and typically made available to free men who volunteered for slavery. ${ }^{54}$ This, as is demonstrated below, is precisely how the "peculium" arose in

$50 \quad 2009: 182$.

51 1984: 6.

52 1951: 220, 222.

532014 .

54 Roth 2005: 290 notes that "no master was obliged to furnish his slaves with peculium allowances". On the other hand, free men were not obliged to contract into slavery. Roth is, I believe, implicitly assuming that slaves were necessarily forcible captives. The possession or not of a peculium was the subject of a negotiation. See, generally, on self-sale, Ramin \& Veyne 1981; Silver 2011a. Probably the proceeds of a self-sale constituted a (first) contribution to the peculium (Brunt 1958: 167). Hegio's instructions (noted above) concerning the necessity specifically to keep in chains free men made into war prisoners lest they fly away are actually addressed to an unchained slave, his lorarius "overseer of slaves" (indicated in the scene-heading). The overseer replies, "omnes profecto liberi lubentius sumus quam seruimus" (meaning, more or less) "[a]ll of us slaves would prefer to be free" (The Captives 120). Hegio responds to his unchained slave who has not flown away: "You, indeed, don't seem to think so" (120), meaning that if the overseer really valued freedom he would build/use his peculium to pay for freedom. This exchange is followed by banter about flight. Hegio knows, because Plautus knows from life experience, that the lorarius is not a war prisoner. He is a taken for granted contractual slave. The contrast is made explicit in lines 206-209 wherein Tyndarus says: "What does he [Hegio] have to fear from us? We know what our duty is if he lets us loose" to which the sympathetic lorarius replies "But you're planning to flee" (tr De Melo 2011). However, the lorarius has no interest in escaping for he is not a liber captivus. Sosia, another of Plautus's unchained slaves who serves the Theban general Amphityron, replies to the god Mercury: “The Thebans call me Sosia, the son of my father Davus" (Plautus Amphityron 365 (tr Riley)). Clearly, he is a contractual slave unless the Theban military captured and enslaved Thebans. 
the eighteenth century trade in "indentured servants" between England and North America. Galenson ${ }^{55}$ reports an estimate that "between one-half and two-thirds of all white immigrants to the British colonies between the Puritan migration of the 1630s and the Revolution came under indenture" - that is, they came as voluntary slaves. On the other hand, I know of no historical episode in which peculia were granted to forcible captives.

Obviously, owning a slave was valued by owners. Ownership of a slave increased an owner's opportunity to invest in very large or very small market or non-market activities, without having to bear the costs (time and money) of closely monitoring the enslaved actors. Entrepreneurially orientated individuals might also invest in and profit from forming human capital in their slaves knowing that the latter lacked the legal right to directly market their augmented skills. ${ }^{56}$ It must be recalled that owners did not, as in an economics text-book, simply contract for a claim on the future labour services of the self-seller but rather on his way of life and physical well-being. ${ }^{57}$ The seller/mortgager of himself - the slave - agreed to a totalitarian relationship in which the buyer was granted recourse to his body and the right to inflict corporal punishment for insubordination. The slave is "subject to alien law" (alieno iuri), that is, slaves are under the "power of their masters" (potestas dominorum). ${ }^{58} \mathrm{~A}$ slave deemed to have failed in his assigned duties was answerable to the owner with his body and, whether maid or merchant, might be liquidated in the slave market. A voluntary slave was a slave subject to all the controls inherent in that status.

For the self-seller having a peculium was valued because the individual might employ it to accumulate funds for purchasing freedom and with it the prized Roman citizenship and/or for setting up an enterprise after manumission for raising his/her current and future living standard. With respect to building a peculium for investing in a business, it may be objected that self-sale is unnecessary as bankers and other lenders were plentiful in the Roman economy. This perspective overlooks that possession of collateral and/or the commitment of an initial investment capital to the business (the peculium) enable the investor/borrower (the freedman) to better negotiate with risk-averse lenders for a larger loan and for a lower interest rate. Totally unsecured loans are rare. ${ }^{59} \mathrm{In}$ a most interesting passage, Seneca ${ }^{60}$ advises Lucilius:

Thus, the noted investor Cato the Elder (Plutarch Cato the Elder 21 7; cf 21 5) "used to lend money ... to those of his slaves who wished it, and they would buy boys (pais) with it, and after training and teaching them for a year, at Cato's expense, would sell them again. Many of these Cato would retain for himself, reckoning to the credit of the trainer the highest price bid for the trainee" (tr adapted from Perrin 1914). Note that the "boys" purchased for enslavement and training might be slave or free.

57 Silver 2011a: 94-95.

58 Inst 148 \& 52; Schumacher 2011: 591.

59 See, eg, Steijvers \& Voordeckers 2009.

60 Letters to Lucilium 119 1-2 (tr Gummere 1925). 
"I shall lead you by a short cut to the greatest riches. It will be necessary, however, for you to find a loan. In order to be able to do business you must contract a debt, although I do not wish you to arrange the loan through a middleman [intercessor], nor do I wish the brokers [proxenetae] to be discussing your rating." Success in business required a loan but for many free natives of the Roman Empire this was not an easy hurdle to clear.

When Cicero ${ }^{61}$ asks: "Is there any doubt about the slavery of people, who because of their covetousness for property (peculium) refuse no condition of the harshest slavery (servitus)?"62 he is reminding (and warning) his affluent readers about the distasteful behavior of those who volunteer for slavery.

Unfortunately, there are no real life Roman texts in which individuals directly explain why they sold themselves into slavery. However, one overlooked text shows us a self-seller who was motivated by building a large peculium for investment. Pliny the Elder ${ }^{63}$ tells that "during the reign of Claudius, a Thessalian eunuch, the freedman (libertus) of M Claudius Marcellus Aeserninus, who ... from motives of ambition (potentia) had enrolled himself (adoptasset) in the number of freedmen of the emperor, and had acquired very considerable wealth, introduced the plane into Italy, in order to beautify his country-seat: so that he may not inappropriately be styled a second Dionysus". As one cannot become an imperial freedman without first becoming an imperial slave, the obvious explanation of his self-enrollment is that this free individual (he was already a freedman) volunteered to become an imperial slave in the (justified) hope of reaping future commercial gains. ${ }^{64}$ With respect to motivation for self-enslavement, note also a family letter about pregnancy of the second century CE from Roman Egypt ${ }^{65}$ wherein an otherwise unknown Herminos is said to have "gone off to Rome and become a freedman of Caesar so he can get official posts". ${ }^{66}$ It may be understood that recruiters gave preference to bright young volunteers for slavery who might be trained in an imperial (or private) paedagium. ${ }^{67}$

61 Paradoxa Stoicorum 539.

62 An eorum servitus dubia est, qui cupiditate peculii nullam condicionem recusant durissimae servitutis? (tr by Cohen 1951: 138).

63 See Natural History 12512 (tr Bostock \& Reilly 1855).

64 For self-sale by freedmen, note $C J 71619$ (293 CE) dealing with a case in which one Paulus protests that a slave manumitted by him (hence a Roman citizen) agreed to become the slave of someone else (consentiat servituti). Also, in Plautus's The Twin Brothers (1149), the slave Messenio having been freed by his master says: "But I need a better start, so that I stay free forever" (tr Rawson 1993: 225). He does finally obtain the right to serve as auctioneer of a substantial property. Rawson 1993: 225 thinks Messenio was worried about becoming a debt-slave. I would suggest he was thinking of having to sell himself back into slavery in order to obtain capital to set up in business. Meijer 2003: 51 notes ex-gladiators who reapplied for gladiator status after fulfilling their contractual obligations (see below on gladiators as voluntary slaves).

65 See Papyrus Oxyrhynchus 3312, lines 10-13.

66 Translated by Rowlandson 1998: 264 no 219.

67 See Mohler 1940: 270-271. 
Understood broadly as a type of economically valuable asset (but not in the strict juristic sense), the peculium might take the form not only of cash, slaves, and material assets but also of human capital as when the master paid the volunteer's transportation expenses to Rome (locational capital) and/or when the master bore the cost of vocationally training or educating him (recall the example of Cato the Elder). "Why did Roman masters free so many slaves?" asks Hopkins. ${ }^{68}$ Because there were so many self-sellers who saw an advantage in serving as slaves and negotiated for a reasonable opportunity to become free. ${ }^{69}$ Market prices were adjusted accordingly. The peculium was a "major reinforcement" of the slave system because by offering it, buyers attracted volunteers for enslavement. The insertion of peculium clauses in self-sale contracts might be roughly understood in terms of creating liens on sold slaves. $^{70}$

That Romans distinguished between the forcibly enslaved and self-selling slaves is suggested when Seneca ${ }^{71}$ lectures Nero that he should treat justly free persons of all statuses (freedman, freeborn, elite) and, for the same reasons, to "spare even captives (captivus) and purchased slaves (mancipiis)". ${ }^{72}$ There would be little reason to mention captives and purchased slaves separately if there was no difference in

68 1978: 117.

69 That individuals found reasons to freely contract into slavery may cast light on a discussed question (Andreau 2009: 122). Why did slaves and former slaves themselves own slaves? I propose that the typical former slave saw nothing shameful about his former status and therefore saw nothing shameful or contradictory about seeking to profit by using the services of the next generation of upwardly mobile volunteer slaves. Indeed, freed slaves as a social category sui generis probably harbored feelings of solidarity for newcomer slaves and so did others freed in the more distant past ( $c f$ George 2005: 51, 54). We have here the makings of a social class "in the modern sense". Petronius (Satyricon 57 5-11) makes the manumitted self-described contractual slave Hermeros aware of and proud of his achievement: "I am a man among men (homo inter homines); I walk about bare-headed [undisguised and unashamed]; I owe nobody a brass farthing; I have never been in the Courts ... I prefer my reputation to any riches ... These are the real victories: for being born free is as easy as saying 'Come here"" (tr Heseltine 1969). But the Satyricon is fiction and it will of course be objected that Petronius, himself a member of the elite, did not and could not accurately convey the attitudes of former slaves. However, in a funerary inscription of $100 \mathrm{BCE}$, one Aulus Granius, like the fictional Hermeros, is proud of his achievements and status: "Here lie the bones of Aulus Granius, an auctioneer and herald, a man of honor, integrity, and great trustworthiness. He wanted you to know this. Aulus Granius, auctioneer and herald, freedman of Marcus" (CIL 1 2 1210; tr Shelton 1998: 197, Text 237). The tomb-reliefs of freedmen demonstrate the pride they took in their stable familial relationships and Roman citizenship (see Zanker: 1975). It seems that, as in Petronius, freedmen may well have had an in-your-face sense of honour!

70 Leges mancipio dictae; see, further, 5 infra.

71 On Clemency 1181.

72 Servis imperare moderate laus est. Et in mancipio cogitandum est, non quantum illud impune possit pati, sed quantum tibi permittat aequi bonique natura, quae parcere etiam captivis et pretio paratis iubet. Quanto iustius iubet hominibus liberis, ingenuis, honestis non ut mancipiis abuti sed ut his, quos gradu antecedas quorumque tibi non servitus tradita sit, sed tutela. Servis ad statuam licet confugere (tr by Joshel 2011: 231). 
treatment and, indeed, if all or virtually all slaves were captives. Seneca does not mention home-born slaves. Note that from a Roman Empire perspective a captive slave sold by one resident to another does not shift the slave to purchased status. Seneca's dichotomy refers to captives and slaves purchased from themselves.

There is also the case of "the dog that did bark". Rome's Edict of the Curule Aediles $^{73}$ requires vendors to make explicit to purchasers that a slave has been chained, preferably by displaying him in chains, or has attempted escape. ${ }^{74}$ Why bother stating the obvious? The implication of the rules is that having been chained and attempting to escape are not routine "defects" that would be taken for granted by purchasers of slaves. Macer, ${ }^{75}$ as noted earlier, anticipates that a criminal slave who was whipped and then returned to serve the remainder of his sentence in chains (vincula) might not be accepted back by his owner. Yet there is no reason to believe that the resistance and the motivation of captives to escape had dissipated during the interval separating Plautus ${ }^{76}$ and Pomponius. ${ }^{77}$ One way of understanding the need for the chaining rule is that the typical slave on the market was (or had become) a volunteer.

It is most informative to compare the forcibly-taken Corsicans who in fact were not valued as slaves with those ethnic groups who were regarded as "born slaves" - specifically "Jews and Syrians" substantial body of evidence suggests that the numerous slaves from Syria and the Greek East attested in Rome during the late Republic and earlier Empire were not prisoners of war or victims of kidnappers ${ }^{80}$ Slaves from the eastern Mediterranean wished especially to come to Rome itself and they (or sometimes their parents) volunteered for enslavement as the best available vehicle to fulfil their material needs and ambitions. Whether the Jews "born for slavery" were also volunteers is more debatable. It is well to note that Rome knew a large Jewish community before there was any large influx of forcible captives. ${ }^{81}$

Large numbers of prisoners were captured by Pompey during his war in Judaea in $63 \mathrm{BC}$ and brought to Rome for his triumph in 61 , but this does not explain the existence of the secondcentury $\mathrm{BC}$ community, which may have consisted of a small number of free immigrants and individuals who reached Rome through the slave trade. The Jews, acting collectively, were a significant factor at public gatherings (contiones) in $59 \mathrm{BC}$, which seems too early for substantial numbers of Pompey's prisoners to have been manumitted. The politically active Jews of 59 were presumably Roman citizens, which implies that they were themselves freedmen or the descendants of freedmen; at this date few free immigrants from the East

74 Arzt-Grabner 2010.

75 D $481910 p r$.

76 Circa 254-c 184 BCE.

77 Mid-second century CE 78.

79 Cicero On the Consular Provinces 2510.

80 Livy 3617 4-5.

81 Noy 2000: 36 esp at $n 33$. 
must have had citizenship. It seems therefore that Jewish slaves must have been reaching Rome in the late second and early first centuries BC, achieving manumission (which implies that they were doing skilled work rather than being used as forced labour) and establishing themselves as a significant and recognizable presence in the city. ${ }^{82}$

Speaking of an early Jewish presence in Rome, Philo ${ }^{83}$ remarks: "And they were mostly Roman citizens, having been emancipated; for, having been brought as captives into Italy, they were manumitted by those who had bought them for slaves, without ever having been compelled to alter any of their hereditary or national observances." It is doubtful that purchasers would have treated Pompey's prisoners of war (if this is Philo's reference) with such consideration and sensitivity. ${ }^{84}$ However, volunteers, especially skilled volunteers, might have contracted for religious respect. The Syrians, Asiatic Greeks and arguably Jews were disdained as "born slaves" because they had mainly volunteered for slavery and consequently could be trusted with a peculium. ${ }^{85}$

82 Idem 256.

83 On the Embassy to Gaius 23155 (tr Yonge (sd)).

84 Hezser 2011: 440-441.

85 Some slaves with a peculium were the children of self-sellers. These vernae predictably shared the relatively positive outlook of their volunteer parents just as any enslaved children of forcibly enslaved parents would mostly share their parents' resentment. The postulated difference in emotional status has important implications for trustworthiness and economic productivity. However, despite the heroic efforts of Sigismund Nielsen (1991) and Herrmann-Otto (1994, 2004) very little is known about the origins and careers of individuals described as vernae. There is one noteworthy exception. Suetonius (On Grammarians 23) tells that Q Remmius Palaemon was the verna of a woman who trained him as a weaver in the earlier first century CE. Palaemon went on to found a school, to own shops for ready-made clothes, and to develop new, very productive vines. That he was "of Vicentia" (a town in the territory of Venetia) I understand to mean that his parents were free natives who volunteered for slavery. Tacitus (Annals 1444 ) maintains: "To our ancestors the temper of their slaves was always suspect, even when they were born on the same estate or under the same roof, and drew in affection for their owners with their earliest breath. But now that we have in our households nations with different customs to our own, with a foreign worship or none at all, it is only by terror you can hold in such a motley rabble" (tr Church \& Brodribb). Upon further reflection I now believe that Tacitus is actually referring to the uneasy relationship between owners and voluntary slaves ( $c f$ Silver 2011a: 96). Voluntary slaves were really slaves and slavery was most unpleasant. In any event, Tacitus does not regard vernae as much more trustworthy than their parents. By contrast, according to his biographer Nepos, Atticus "kept an establishment of slaves of the best kind, if we were to judge of it by its utility, but if by its external show, scarcely coming up to mediocrity; for there were in it well-taught youths, excellent readers, and numerous transcribers of books, insomuch that there was not even a footman that could not act in either of those capacities extremely well. Other kinds of artificers, also, such as domestic necessities require, were very good there, yet he had no one among them that was not born and instructed in his house; all which particulars are proofs, not only of his self-restraint, but of his attention to his affairs; for not to desire inordinately what he sees desired by many, gives proof of a man's moderation; and to procure what he requires by labour rather than by purchase, manifests no small exertion" (Life of Atticus 13 2-4 (tr Watson) (accessed 17 Oct 2015) available at http://www.attalus.org/translate/atticus.html). Unfortunately, Nepos provides no hint of the parentage of Atticus'vernae. 
There is also evidence bearing on the expected treatment of young contractual slaves in post-Roman times (recall Cato's young captives). In $527 \mathrm{CE}$, Cassiodorus ${ }^{86}$ describes, in a letter drafted for the Ostrogoth king Athalaric, the marketplace of Lucania in southern Italy: "Boys and girls are on display, marked out with the differences in sex and age, brought to the market not as captives, but by freedom: their parents are right to sell them, since they benefit by slavery. Indeed, there is no doubt that slaves can be improved by transference from field work to service in town (urbana servitia)." ${ }^{\circ 7}$ Note that Cassiodorus twice describes the sold children as slaves (servi) and it is reasonable to assume that he understood the meaning of the term. For Cassiodorus the sale of the children into slavery is a means for upgrading their economic prospects (probably via vocational training) and, hence, he does not wish the practice to be made illegal as it was elsewhere under Germanic rule. ${ }^{88}$

The scene described by Cassiodorus provides the key for understanding a provision in Roman law reported by Ulpian: ${ }^{89}$ "Vivian goes on to say that if a slave leaves his master and comes back to his mother, the question whether he be a fugitive is one for consideration; if he so fled to conceal himself and not to return to his master, he is a fugitive; but he is no fugitive if he seeks that some wrongdoing of his may be better extenuated by his mother's entreaties." The "mother" the slave returns to is obviously located outside the jurisdiction of the master and given the expectation of "entreaties" she may be identified as the free woman who sold (or exposed) her child into slavery to improve his/her life prospects. ${ }^{90}$ She would (re)emphasise this motivation to the child just as would a woman who had volunteered for slavery and later borne (enslaved) children. No forcibly enslaved mother could make this kind of affirmative explanation to her slave born offspring or pacify his owner.

Some scholars may nevertheless object that a volunteer is not really a slave. ${ }^{91}$ The only meaningful test of definitions is whether they are coherent and fruitful. Let it be noted, however, that if contractual slaves are excluded then the Roman Empire must be "demoted" from the status of "slave society". ${ }^{2}$

$86 \quad 8334$.

87 Translated by Barnish 1992: 10.

88 See Vuolanto 2003: 186.

89 D 211175.

90 The validity of this interpretation is reinforced by another testimony from Roman times. Writing at the end of the second century CE, Tertullian of Carthage (The Apology 9) disdainfully remarks: "You first of all expose your children, that they may be taken up by any compassionate passer-by, to whom they are quite unknown; or you give them away, to be adopted by those who will do better to them the part of parents" (tr Thelwall in Roberts 1994/1995).

91 This is like saying that someone who is fasting (starving himself) instead of being starved by someone else is not really hungry. Contractualism undoubtedly complicates socio-economic analysis but it sometimes appears that the main problem is that it distracts from the effort to prosecute Rome for atrocities committed in the antebellum South.

92 Finley 1980: 125-160; Bradley 1987: 14-15; Harper 2011: 39-40, 60-61. 


\section{Some evidence for slave markets serving volunteers}

There are several particularly relevant testimonies that Rome knew structured slave markets serving those who wished to volunteer to become slaves. ${ }^{93}$

(1) Seneca suggests: ${ }^{94} \mathrm{~A}$ benefit has in view the advantage of him upon whom we bestow it, not our own ... Many things, therefore, which are of the greatest possible use to others, lose all claim to gratitude by being paid for. Merchants are of use to cities, physicians to invalids, dealers [mangones] to slaves, yet all these have no claim to the gratitude of those whom they benefit, because they seek their own advantage through that of others. ${ }^{95}$ How precisely did mangones make themselves useful to self-sellers? How else but by becoming familiar with the volunteer's preferences and abilities, helping him to negotiate price and placement, and possibly acting as a fiduciary seller incorporating various covenants in contracts transmitting free men from themselves to their new owners? Moreover, as the seller, the dealer would be in a position to help the slave to enforce the contract with his/her owner including perhaps by means of seizure (manus iniectio). ${ }^{96}$

(2) Reputable free persons sold themselves (or were sold by parents) into slavery to qualify themselves to obtain otherwise unattainable sensitive private and public positions such as actor (steward), procurator (financial manager) or vilicus/vilica (manager of a rural estate) ${ }^{97}$ The most important legal text is that of Ulpian in Digest 28365 , wherein the phrase ad actum gerendum pretiumve participandum ("to

93 See, also, Silver 2011a, 2013, 2014, 2015.

94 On Benefits 4133.

95 Translated by Gummere 1925, emphasis added.

96 See McGinn 1990: 342-343. In Lucian of Samasota's "Sale of Philosophies" (Vitarum Auctio 7) dating to the mid-second century CE we find Zeus and Hermes selling philosophers: "Zeus. They are welcome to him. Now up with the next. Hermes. What about yonder grubby Pontian? Zeus. Yes, he will do. Hermes. You there with the wallet and cloak, come along, walk round the room. Lot No. 2. A most sturdy and valiant creed, free-born. What offers? Second Dealer. Hullo, Mr. Auctioneer, are you going to sell a free man? Hermes. That was the idea. Second Dealer. Take care, he may have you up for kidnapping (andrapodiomos). This might be a matter for the Areopagus. Hermes. Oh, he would as soon be sold as not, He feels just as free as ever. Second Dealer. But what is one to do with such a dirty fellow? He is a pitiable sight. One might put him to dig perhaps, or to carry water. Hermes. That he can do and more. Set him to guard your house, and you will find him better than any watch-dog - They call him Dog for short" (tr Fowler \& Fowler 1905). The buyer raises the concern that the free man will claim that he was kidnapped. Hermes explains that the free man wishes to be sold. This seems to satisfy the dealer for at the end he is concerned only with how the purchased slave's services might be utilized. Hermes, like a good dealer, speaks favorably of the self-seller's (apparently limited) skills. I owe to Egbert Koops the thought that self-sellers might be transmitted by fiduciary sellers to final purchasers by means of a sale ut manumittatur or by another restrictive covenant (D 40 8; Buckland 1908: 628-646; McGinn 1990).

97 See 4 supra. 
performing an act or sharing in the price") denotes precisely self-sale behavior; see, also, Theodosian Code $486 .{ }^{98}$ Also, in a difficult passage, Augustine writes: "After all, free men are often asked to be stewards, and they think they gain an advantage if they do what they are asked to do ... If a free man became a slave as a result of this advantage ..." 99

As noted below, some (disreputable?) people found it worthwhile to sell themselves into slavery to be trained and serve profitably as gladiators. Also, in Plautus (Curculio 482) the choragus ("property manager") informs Curculio: "In the Tuscan Quarter there are those persons who sell themselves." 100 The property manager's reference to self-sale in the Tuscan Quarter is embedded in a recognisable tour around the south side of the Forum Romanum. For this and other reasons, there is no reason to assume it refers, or refers only, to the sale of sexual services. ${ }^{101}$

Again, after referring to some rather distasteful Roman occupations (draining sewers and carrying corpses), Juvenal refers to those "[w] ho offer themselves for sale according to auctioneers' rules". ${ }^{102}$ The meaning is that in return for the opportunity to climb up the occupational ladder, a Roman might be willing to be sold/auctioned into slavery and in so doing surrender his freedom or citizenship (diminish his legal status or caput). ${ }^{103}$

Most directly, Dio Chrysostom, ${ }^{104}$ who came to Rome in the later first century $\mathrm{CE}$, composed a dialogue in which a citizen responds to a question put to him by a slave: "But what do you mean by saying that I might become a slave?" The slave explains: "I mean that great numbers of men, we may suppose, who are freeborn sell themselves, so that they are slaves by contract (Greek: doulouein kata syggraphèn), sometimes on no easy terms but the most severe imaginable." ${ }^{105}$ Harrill suggests that doulos (slave) here means something less than or different from real slavery: ${ }^{106}$ "The interlocutor ... refers to educated Greeks who contract themselves not into chattel bondage but a kind of indentured servitude ... for a specified time.

98 D 2836 5: "Erratum fit testamentum, quotiens ipsi testatori aliquid contigit, puta si civitatem amittat per subitam servitutem, ab hostibus verbi gratia captus, vel si maior annis viginti venum se dari passus sit ad actum gerendum pretiumve participandum." Based on an erasure, ad actum gerendum might be a later interpolation (a new law) or perhaps the compilers worked with an edition of Ulpian ad Sabinum where it was already in the original text.

99 Letters 24* 2; tr Teske 2005.

100 "In Tusco vico, ibi sunt homines qui ipsi sese venditant" (tr De Melo 2011).

101 Silver 2014.

102 Juvenal 3 33: "Et praebere caput domina venale sub hasta" (tr Kline, available at http://www. poetryintranslation.com/PITBR/Latin/JuvenalSatires3.htm\#anchor_Toc281039203). For the symbolism of the spear at auctions, see Seneca the Elder (Declamations 933 ).

103 D 45 3pr-1; Silver 2011a: 87.

104 Discourses 1523.

105 Translated by Cohoon 1939, emphasis added.

106 1995: 31. 
Presumably, the indentured servants neither contracted themselves permanently nor included their children, both of which are essential to chattel slavery." One may well wonder whether a soldier enslaved on a battlefield and sold to slave traders is really a "chattel slave" when his wife, children and other family members lodged far from the battlefield remain free. The point remains that an "educated Greek" who sold himself into slavery was legally transferable and answerable to his owner with his body - that is, he is unquestionably a "chattel" slave. ${ }^{107}$

Harrill is correct in noting the resemblance between Roman "slavery by contract" and the later practice known as "indentured servitude" in which, despite the circumlocution, it is very clear that chattel slavery with a peculium (and other benefits) was the outcome of a contractual transaction involving free individuals. The essential features of this popular transaction have been summarised by Galenson: ${ }^{108}$

It [indentured servitude] functioned through two markets linked by a recruiting agent. In England, in the first market, a prospective servant signed a contract, or "indenture," with a merchant, promising to serve the latter or his assigns in a particular colony for a given period under stated conditions. The servant was then transported to the specified [North American] colonial destination, where the merchant or his representative sold the contract to a colonial planter or farmer in the second market ... Once signed, the indenture was negotiable property, and at any time before its conclusion the servant could be sold to a new master for the balance of his term .... There were a number of potentially variable dimensions to the contract. These included the length of the term for which the servant was bound and the amount of freedom dues he was to receive [upon completing his indenture]. Provisions could be inserted into the contract for cash payments to be made to the servant, either as an initial lump sum or as a salary during the course of the contract. Restrictions could also be placed on the kind of work the servant could be required to perform ... [S]ervants were universally subject to strict requirements of specific performance of their contractual obligations by colonial courts and were subject to harsh punishments for attempts to avoid them ... And although colonial laws protected servants from excessive corporal punishment, and masters who killed their servants would be tried for murder, masters generally were permitted considerable latitude in beating their servants.

The merchant in effect acted as a fiduciary seller of the "indentured servant" whose contract was fully transferable. With respect to the corporal punishment of servants, a Maryland law of the eighteenth century permitted ten lashes for a single offense or as many as thirty lashes with the approval of a Justice of the Peace. ${ }^{109}$ The payment for the ocean passage of the "servant" plus any occupational or language training plus any initial lump sum payment plus any salary paid plus "freedom dues" can be viewed as functional equivalents of the Roman peculium.

107 Note, also, that several Roman legal texts suggest that individuals might sell themselves into slavery while other members of their families remained free (see D 4012 1pr 1, 2; D 471015 ).

108 1981: 97, 98, 171; 1984: 8.

109 Steinfeld 1991: 45-46. 
Indeed, the "freedom dues" paid upon completion of the indenture corresponds to the peculium liberti, a grant of patrimony mentioned in the Formulae Visigothicae ${ }^{110}$ for manumission. ${ }^{11}$ Scholars believe that the Formulae were written down in about 620 CE. Córcoles Olaitz concludes that "the influence of the Roman law in the theory of the Visigothic donation is determinative". ${ }^{112}$

(3) Roman self-sellers, like English indentured servants, might volunteer to serve for a limited term. An inscription ${ }^{113}$ from Smyrna dated to the second or third century concerns one Erichthonius who died at the age of twenty-eight when it appears there was an obligation (deberet) to manumit him at thirty. ${ }^{114}$

There is additional inconclusive (but potentially powerful) evidence that Roman self-sellers, like English indentured servants, might insert clauses into their selfsale contracts. Besides incorporating a legally recognised manumission clause (ut manumittatur), self-sellers might negotiate a sales clause calling for them to be exported (ut exportetur) (or not to be exported) or a covenant which forbade the buyer to prostitute them (ne serva prostituatur). ${ }^{115}$

Indeed, although not mentioned in the legal sources, contractual clauses mandating a peculium ${ }^{116}$ or occupational training or some other benefit for the slave are quite possible. Thus, although McGinn ${ }^{117}$ expresses doubts concerning benefits to the public of extending the range of legally recognised covenants (beyond prostitution, export, and manumission) restricting the buyer's rights of ownership over his slave he acknowledges that "( $t$ )heoretically, it might be possible to frame any agreement regarding the slave after sale, at least on a contractual basis". Koops (forthcoming) reasons: "This construction of transfer ut manumittatur was particularly suited to cases of self-sale into slavery, since it allowed the self-seller to negotiate the conditions of future manumission (including the grant of a peculium) and gave him legal redress, through still a slave, if the conditions were met, but manumission did not follow." 118

Admittedly, I cannot cite a legal case specifically dealing with a peculium covenant and this weakens my argument for contractual flexibility. On the other

110 For example $F V 2$.

111 Cf Schumacher 2011: 600.

112 2006: 347 with $n 47$ citing the legal background.

113 RMO Leiden unpublished EDCS-58700011.

114 Dis manibus / Ericthonio animae / sanctissimae-hic/cum deberet ann(is) XXX/manumitti ann(os) XXIIX / decessut / C(aius) Cilnius-Philetus / filio carissimo /fec(it). See Koops (forthcoming), cited with permission.

115 D 187 6; D 4086 1; McGinn 1990; Buckland 1908: esp 69-72, 628-640.

116 See 4 supra.

117 1990: 319-320 with n 14, 345-346.

118 Quoted with permission. 
hand, Roman law reinforced long traditional practices in providing a kind of omnibus solution for disputes between masters and slaves. Slaves taking refuge at a statue of the emperor were entitled to an official hearing about their varied complaints with the possible outcome that they had to be sold to a new, more congenial master. The legal authorities wished the "complaints" lodged by slaves to involve gross illegalities, not mere "accusations" against masters. ${ }^{119}$ Nevertheless, the responsible officials were kept busy as is resentfully reported by Tacitus ${ }^{120}$ and as is suggested by the analogical reference to hordes seeking refuge in C Th 627 18. Perhaps a few slaves used refuge to gain an audience for vindictively motivated charges, ${ }^{121}$ but most would have been deterred from pursuing revenge by the danger of being branded a fugitive and the threat of reprisal. Some of those who took the chance would have been concerned with mending broken agreements concerning such matters as the granting of a peculium. ${ }^{122}$ Moreover, slaves might take refuge at an altar. As explained by Naiden, ${ }^{123}$ a statue of the emperor is not the same as a shrine: "At a shrine, supplicants are inviolable until a decision is rendered; at a statue they are subject to transportation... A shrine offers protection in the same manner as any other altar, and an altar does not have to be [legally] regulated. As regards supplication, private altars are never regulated."

More generally, contractual rituals rehearsed under the auspices of gods may well have played the decisive role in enforcing covenants in self-sale transactions. That is, priests played a more important role than prefects. Did volunteer slaves and purchasers build mutual trust (fides) by swearing mutual contractual oaths? As noted earlier, Visigothic Spain had explicit formulas (the Formulae Visigothicae) that probably had to be publicly rehearsed when individuals sold themselves into slavery. Formula Visigothicae 32, for example, explicitly mentions the willingness of the seller to become a slave (he takes an oath) in order to better his position and the seller's receipt of payment. ${ }^{124}$ It cannot be proven that these formulae were taken over from Roman law but neither is it evident that they are either idiosyncratic or entirely adaptations to a new post-Roman environment. ${ }^{125}$

122 Seneca (On Benefits 322 3), writing in about the mid-first century CE, remarks: "Now an official has been appointed to hear complaints of the wrongs done by masters to their slaves, whose duty it is to restrain cruelty and lust, or avarice in providing them with the necessaries of life" (tr Stewart 1887 (accessed 12 Dec 2015) available at http://en.wikisource.org/wiki/On_Benefits). This formulation seems to leave flexibility for pursuing contractual breaches: "He [the prefect of the city] is to give a hearing to slaves who have taken refuge by the statue or who have paid with their own money for their manumission, when they make complaints against their masters" (D 11211 Ulpian).

123 2006: 256.

124 See Díaz 2007; $c f$, too, Rio 2011: 9-15.

125 See Córcoles Olaitz 2006: 347-348. 
For explicitly Roman times, note Petronius: ${ }^{126}$

So to keep the lie safe among us all, we took an oath [sacramentum gladiatorum or better the auctoramentum gladiatorum] to obey Eumolpus; to endure burning, bondage, flogging, death by the sword, or anything else that Eumolpus ordered. We pledged our bodies and souls to our master most solemnly (religiosissime), like regular gladiators. When the oath was over, we posed like slaves (servilis) and saluted (consaluto) our master (dominum) ..."

The final sentence describing the binding outcome of the oath resonates, especially since it is estimated that by the first half of the first century CE more than half of gladiators were auctorati, that is, free men who were paid money by gladiator managers and thereby assumed slave status contractually. ${ }^{127}$

\section{Economic growth and the peculium economy: Conclusion}

The prime engine of economic growth is the accumulation of capital, physical and human. Individuals differ in their ability and motivation to accumulate capital by means of investment. Moreover there is no necessary congruence between initial endowments of capital and the ability/motivation to invest it productively. For maximum growth to occur, the capital market must transfer resources from less to more productive users/uses. This transfer process is inhibited by (what economists call) "imperfections" in the capital market which basically arise from the cost to lenders of securing repayment from borrowers. A loan can be offered (be economic) only when the expected value of the resources used up to collect repayment is less than the net proceeds of the loan. Thus, innovations reducing loan-collection costs would, other things remaining equal, increase lending, investment and economic growth.

The ancient world generally, and Rome in particular, innovated in two very special (interrelated) ways to reduce/avoid loan-collection costs, namely by means of the institutions of contractual slavery and of the oath. With respect to the first, in Rome an individual could pledge his body to a lender; ${ }^{128}$ or, the main theme in the present paper, the individual could sell his body to a purchaser. Self-sale fostered economic growth by facilitating the movement of labor power from regions of lower to regions of higher labor productivity. To understand the pro-growth contribution of self-sale note first that the direct cost of transportation of a human being to Rome from (say) Asia Minor might be relatively high and that to this cost would have to be added the cost (foregone earnings plus direct search costs plus vocational training;

126 Satyricon 117 4-6 (tr Heseltine 1969).

127 For more on gladiators, see Barton 1993: 13-24; Carter 2003: 104-105 with n 72; Crook 1967: 61; Edwards 1997: 77; and Meijer 2003: 51.

128 Silver 2012: 236-238: note the tale of Lacaena in n 32 supra. 
plus language acquisition) of acclimatising the migrant in a new environment. ${ }^{129}$ Local lenders to prospective migrants who sought to take advantage of differences in productivity would easily be deterred by the cost of enforcing loan repayments with free migrants over distances and across political jurisdictions. A more cost-effective alternative was for local merchants (slave dealers) to purchase local volunteers for migration and then to resell them in Rome to a middleman or final user. As has been stressed in this article, free individuals were encouraged to sell themselves into slavery by the promise of sharing in the economic gains generated by the movement of their labor power from less to more economically dynamic regions. The grant of a peculium to voluntarily enslaved migrants was the main device by means of which the sharing of gains was pre-arranged between capitalists and workers.

The problem of flight by self-sellers (including flight to non-owning Roman employers) was to be managed (never eliminated) by means of mutually advantageous ongoing relationships between the contracting parties (eg training, contacts, advances of capital) and, most importantly, by means of joint appeals to the gods - that is, mutual loyalty oaths. Ritualised oaths were sworn not only, as is well known, when slaves were transformed from things into persons (by being manumitted), but also when persons were transformed into things (by self-sale).

Antiquity teaches that modern technology and impersonal enforcement of contracts by states are not required to build a growing market economy. Self-sale into slavery and oaths were excellent substitutes. More specifically, this article has argued that the vast superstructure of the Roman peculium economy was erected by contract, not by force and that its base was formed by individuals who had sold themselves into slavery in order to advance their material and social interests.

\section{Abstract}

Why did Roman slaves have a peculium or purse? It has been suggested that the grant of a peculium was a clever arrangement, a trick actually, by means of which owners incentivised slaves to perform unsupervised labour. Upon this incentive base stands Rome's "peculium economy" in which diverse and far-flung business and other activities are performed by minimally supervised slaves. However, forcibly taken slaves (including born-slaves), the kind still taken for granted in the scholarly literature, would not be sufficiently incentivised by peculia. The "peculium economy" stands, however, because the slaves forming its base are slaves by contract/self-sellers. The peculium, the legal and other evidence suggests, is a contractual benefit desired

129 See Noy 2000: 141-144, 149-152. More generally, oath-taking and ritualised contracting substituted for contemporary means of communication in reducing total transaction costs and thereby facilitating extensive market behavior (Silver 2004; Silver 2011b: esp 51-60). To put it starkly, where modern society relies (imperfectly) on technology, the ancients relied (imperfectly) on gods and rituals. The oath-curse mechanism in particular provided antiquity with a measure of social control otherwise prohibitively expensive or unavailable. 
by and typically made available to free individuals who volunteered for slavery. This is precisely how, for example, the "peculium" arose in the eighteenth century trade in "indentured servants" between England and North America. The paper explores this finding and develops its implications for Roman economic growth.

\section{Bibliography}

Andreau, Jean (2006) "Roman law in relation to banking and business: A few cases" in Bang, Peter F, Ikeguchi, Mamoru \& Ziche, Hartmut G (eds) Ancient Economies, Modern Ideologies: Archaeology, Comparative History, Models and Institutions (Bari): 201-213

Andreau, Jean (2009) "Freedmen in the Satyrica" in Prag, Jonathan \& Repath, Ian (eds) Petronius: A Handbook (Malden, Mass): 114-124

Arzt-Grabner, Peter (2010) "Neither a truant nor a fugitive': Some remarks on the sale of slaves in Roman Egypt and other provinces" in Gagos, Traianos (ed) Proceedings of the TwentyFifth International Congress of Papyrology, Ann Arbor 2007 (Ann Arbor, Mich): 21-32

Aubert, Jean-Jacques (2009) "Productive investments in agriculture: Instrumentum fundi and peculium in the later Roman Republic" in Carlsen, Jesper \& Cascio, Elio Lo (eds) Agricoltura e scambi nell'Italia tardo-repubblicana (Bari): 167-185

Barnish, SJB (1992) Cassiodorus: Selected Variae (Liverpool)

Barton, Carlin A (1993) The Sorrows of the Ancient Romans: The Gladiator and the Monster (Princeton, NJ)

Beare, Rhona (1978) “Were bailiffs ever free born?” Classical Quarterly 28: 398-401

Bendlin, Andreas (2011) "Associations, funerals, sociality, and Roman law: The collegium of Diana and Antinous in Lanuvium (CIL 14 2112) reconsidered" in Ohler, Markus (ed) Aposteldekret und antikes Vereinswesen: Gemeinschaft und ihre Ordnung (Tübingen): $207-$ 296

Blume, Fred $(s d)$ : “Annotated Justinian Code" available at http://www.uwyo.edu/lawlib/blumejustinian/

Bostock, John \& Riley, Henry T (1855) The Natural History of Pliny (London)

Bradley, Keith R (1984) Slavery and Society at Rome (Cambridge)

Bradley, Keith R (1987) Slaves and Masters in the Roman Empire (New York, NY)

Bradley, Keith R (1989) Slavery and Rebellion in the Roman World, 140 B.C.-70 B.C. (Bloomington, Ind)

Bradley, Keith R (2010) "Freedom and slavery" in Barchiesi, Alessandro \& Scheidel, Walter (eds) The Oxford Handbook of Roman Studies (Oxford): 625-640

Bradley, Keith \& Cartledge, Paul (eds) (2011) The Cambridge History of Slavery. Vol 1. The Ancient Mediterranean World (Cambridge)

Brunt, PA (1958) "Review of Westermann, Tudor and Vogt" J of Roman Studies 48: 164-170

Buckland, Walter Warwick (1908) The Roman Law of Slavery (Cambridge)

Carlsen, Jesper (1995) Vilici and Roman Estate Managers until AD 284 (Rome) 


\section{MORRIS SILVER}

Carter, Michael (2003) "Gladiatorial ranking and the SC DE Pretiis Gladiatorum Minuendis (CIL II 6278 = ILS 5163) Phoenix" The Classical Association of Canada 57: 83-114

Church, Alfred John \& Brodribb William Jackson (1942) The Complete Works of Tacitus (New York, NY)

Cohen, Boaz (1951) "Peculium in Jewish and Roman law" Proceedings of the American Academy for Jewish Research 20: 135-234

Cohoon, JW (1939) Dio Chrysostom: Discourses (Cambridge, Mass)

Córcoles Olaitz, Edorta (2006) "The manumission of slaves in the view of the formulae Visigothicae" Veleia: Revista anual del Instituto de Ciencias de la Antigüedad dedicada al estudio de la Prehistoria, Historia Antigua y Filología y Arqueología Clásicas 23: 339-349

Crook, John (1967) Law and Life of Rome (Ithaca, NY)

De Melo, Wolfgang (2011) Plautus I, II (Cambridge, Mass)

Díaz, Pablo C (2007) "Sumision voluntaria: estatus degradado e indifferencia de estatus en la Hispania" Studia historia/Historia antigua 25: 507-524

Edwards, Catharine (1997) "Unspeakable professions: Public performance and prostitution in ancient Rome" in Hallett, Judith P \& Skinner, Marilyn B (eds) Roman Sexualities (Princeton, NJ): 66-95

Fairclough, H Rushton (1999) Virgil rev ed (Cambridge, Mass)

Finley, MI (1980) Ancient Slavery and Modern Ideology (New York, NY)

Fleckner, Andreas M (2014) “The peculium: A legal device for donations to personae alieno iuri subiectae?" in Carlà, Filippo \& Gori, Marja (eds) Gift Giving and the Embedded Economy in the Ancient World (Heidelberg): 213-239

Földi, András (1996) "Remarks on the legal structure of enterprises in Roman law" Revue Internationale des Droits de l'Antiquité 43: 179-211

Fowler, HW \& Fowler, FG (1905) The Works of Lucian of Samasota (Oxford)

Galenson, David W (1981) White Servitude in Colonial America: An Economic Analysis (Cambridge)

Galenson, David W (1984) "The rise and fall of indentured servitude in the Americas: An economic analysis" J of Economic History 44: 1-26

Gamauf, Richard (2009) "Slaves doing business: The role of Roman law in the economy of the Roman household" European Review of History 16: 331-346

Garnsey, Peter (1981) "Independent freedmen and the economy of Roman Italy under the Principate" Klio. Beiträge zur alten Geschichte 63: 359-371

Gaselee, S (1917) Achilles Tatius (London)

George, Michele (2005) "Family imagery and family values in Roman Italy" in George, Michele (ed) The Roman Family in the Empire: Rome, Italy, and Beyond (Oxford): 37-68

Gummere, Richard M (1925) Seneca: Ad Lucilium Epistulae Morales (Cambridge, Mass)

Harper, Kyle (2011) Slavery in the Late Roman World, AD 275-425 (Cambridge)

Harrill, J Albert (1995) The Manumission of Slaves in Early Christianity (Tübingen)

Hellie, Richard (1982) Slavery in Russia, 1450-1725 (Chicago, Ill) 
Herrmann-Otto, Elisabeth (1994) Ex ancilla natus. Untersuchen zu den "Hausgebrenen" Sklaven and Sklavinnen im Westen des römischen Kaiserreiches (Stuttgart)

Herrmann-Otto, Elisabeth (2004) "Sklavenkinder in Recht, Ökonomie und Gesellschaft des Römischen Reiches" Revue Internationale des Droits de l'Antiquité 51: 167-186

Heseltine, Michael (1969) Petronius (Cambridge, Mass)

Hezser, Catherine (2011) "Slavery and the Jews" in Bradley, Keith \& Cartledge, Paul (eds) The Cambridge World History of Slavery. Vol 1. The Ancient Mediterranean World (Cambridge): 438-455

Hopkins, Keith (1978) Conquerors and Slaves: Sociological Studies in Roman History vol 1 (Cambridge)

Johnson, Allan Chester et al (1961) Ancient Roman Statutes, Translation with Introduction, Commentary and Glossary (Austin, Texas)

Jones, Horace Leon (1924) Strabo’s Geography (London)

Joshel, Sandra R (2011) "Slavery and Roman literary culture" in Bradley, Keith \& Cartledge Paul (eds) The Cambridge World History of Slavery. Vol 1. The Ancient Mediterranean World: 214-240

Ker, Walter CA (1920) Martial Epigrams (Cambridge, Mass)

Koops, Egbert (forthcoming) "The practice of manumission through negotiated conditions in Imperial Rome" in Dari-Mattiacci, Giuseppe (ed) Roman Law and Economics (Oxford)

Laes, Christian (2008) "Child slaves at work in Roman Antiquity" Ancient Society 38: 235-283

McGinn, Thomas AJ (1990) "Ne serva prostituatur: Restrictive covenants in the sale of slaves" Zeitschrift der Savigny-Stiftung für Rechtsgeschichte Rom Abt 107: 315-353. A revised version of this article focusing mainly on prostitution may be found in McGinn 1998: 288319

McGinn, Thomas AJ (1998) Prostitution, Sexuality, and the Law in Ancient Rome (New York, NY)

MacLean, Rose B (2012) Cultural Exchange in Roman Society: Freed Slaves and Social Values (unpublished $\mathrm{PhD}$ dissertation, Princeton, NJ)

Martin, Susan D (1989) The Roman Jurists and the Organization of Private Building in the Late Republic and Early Empire (Brussels)

Meijer, Fik (2003) The Gladiators: History's Most Deadly Sport (New York, NY)

Millar, Fergus (1984) "Condemnation to hard labour in the Roman Empire: From the JulioClaudians to Constantine" Papers of the British School at Rome 52: 124-147

Mohler, SL (1940) "Slave education in the Roman Empire" Transactions of the American Philological Association 71: 262-280

Mouritsen, Henrik (2011) The Freedman in the Roman World (Cambridge)

Naiden, FS (2006) Ancient Supplication (Oxford)

Noy, David (2000) Foreigners at Rome: Citizens and Strangers (London)

Perrin, Bernadette (1914) Plutarch's Lives (Cambridge, Mass) 


\section{MORRIS SILVER}

Ramin, Jacques \& Veyne, Paul (1981) "Droit romain et société: les hommes libres qui passent pour esclaves et l'esclavage volontaire" Historia. Zeitschrift für alte Geschichte 30: 472-497

Rawson, Elizabeth (1993) "Freedmen in Roman comedy" in Scodel, Ruth (ed) Theater and Society in the Classical World (Ann Arbor, Mich): 215-233

Riley, Henry Thomas (1912) The Comedies of Plautus (London)

Rio, Alice (2011) "Self-sale and voluntary entry into unfreedom, 300-1100" J of Social History 45: $1-25$

Roberts, Alexander (1994/1995) The Ante-Nicene Fathers (Peabody, Mass)

Roth, Ulrike (2005) "Food, status, and the peculium of agricultural slaves" J of Roman Archaeology 18: $278-292$

Rowlandson, Jane (1998) Women and Society in Greek and Roman Egypt: A Sourcebook (Cambridge)

Scheidel, Walter (1990) "Free-born and manumitted bailiffs in the Graeco-Roman world" Classical Quarterly 40: 591-593

Schumacher, Leonhard (2011) "Slaves in Roman society" in Peachin, Michael (ed) The Oxford Handbook of Social Relations in the Roman World (Oxford): 589-607

Shackleton Bailey, David R (2014) Letters to Quintus and Brutus; Letter Fragments; Letter to Octavian; Invectives; Handbook of Electioneering (Cambridge, Mass)

Sigismund Nielsen, Hanne (1991) "Ditis examen domus? On the use of the term Verna in the Roman epigraphical and literary sources" Classica et mediaevalia: Revue danoise de philologie et d'histoire 42: 221-240

Shelton, Jo-Ann (1998) As the Romans Did: A Sourcebook in Roman Social History (Oxford)

Silver, Morris (2004) "Modern ancients" in Rollinger, Robert \& Ulf, Christoph (eds) Commerce and Monetary Systems in the Ancient World: Means of Transmission and Cultural Interaction (Stuttgart): 65-87

Silver, Morris (2011a) "Contractual slavery in the Roman economy" Ancient History Bulletin 25: $73-132$

Silver, Morris (2011b) "Transaction/administrative costs in Greco-Roman antiquity with special reference to the implications of atheism/naturalism in classical Athens" Marburger Beiträge zur Antiken Handels-, Wirtschafts- und Sozialgeschichte 29: 49-93

Silver, Morris (2012) "The nexum contract as a "Strange Artifice" Revue Internationale des Droits de l'Antiquité 59: 217-238

Silver, Morris (2013) “Macula Servitutis: The selective stain of Roman slavery" Hephaistos. Kritische Zeitschrift zu Theorie und Praxis der Archäologie und angrenzender Gebiete 30: 53-61

Silver, Morris (2014) "Places for self-selling in Ulpian, Plautus and Horace: The role of Vertumnus" Mnemosyne. Bibliotheca classica Batava 67: 577-587

Silver, Morris (2015) "The role of slave markets in migration from the Near East to Rome" Klio. Beiträge zur alten Geschichte 97 (forthcoming)

Steijvers, Tensie \& Voordeckers, Wim (2009) "Collateral and credit rationing" $J$ of Economic Surveys 23: 924-946

Steinfeld, Robert J (1991) The Invention of Free Labor: The Employment Relation in English and American Law and Culture, 1350-1870 (Chapel Hill, NC) 
Stewart, Aubrey (1900) L Annaeus Seneca: Minor Dialogs Together with the Dialog "On Clemency" (London)

Teske, Roland (2005) “Letters 211-270, 1*-29* (Epistulae)” in Ramsey, Boniface (ed) The Works of Saint Augustine: A Translation for the 21 st Century part 2 -Letters vol 4 (Hyde Park, NY)

Vuolanto, Ville (2003) "Selling a freeborn child: Rhetoric and social realities in the late Roman world" Ancient Society 33: 169-207

Watson, Alan (1998) The Digest of Justinian (Philadelphia, Pa)

Yonge, Charles Duke $(s d)$ "On the embassy to Gaius" available at http://en.wikisource.org/wiki/ On_the_Embassy_to_Gaius

Zanker, Paul (1975) „Grabreliefs römischer Freigelassener“ Jahrbuch des Deutschen Archäologischen Instituts 90: 267-315

Zwalve, Willem J (2002) "Callistus's case: Some legal aspects of Roman business activities" in De Blois, Lukas \& Rich, John (eds) The Transformation of Economic Life under the Roman Empire (Amsterdam): 116-127 